\title{
Pengaruh CG dan Risiko Bank terhadap Kinerja Intellectual Capital yang Dimediasi oleh Capital Structure
}

\author{
AYU SRI PRASETYOWATI \\ STIE Dharmaputra \\ Jl. Pamularsih Raya No. 16 Semarang \\ Email: ayuhartono21@gmail.com
}

\section{Diterima 28 April 2021; disetujui 6 Juli 2021;}

\begin{abstract}
This study aims to examine the effect of corporate governance and bank risk on intellectual capital performance by capital structure. Intellectual capital performance is very useful for the management, especially for managing his company. Intellectual capital performance is useful for management to make decisions about budget and investments. This research about intellectual capital performance is interesting to do because inconsistency of the results of previous research. This study use 135 banking companies. The banking companies used are listed on the Indonesia Stock Exchange for the period of 2017-2019. The method used to test the effect of each variable in this study is multiple regression linear. The results of this study prove that capital structure is able to mediate the effect of bank risk on intellectual capital performance. Capital structure can not mediate the effect of corporate governance on intellectual capital performance.
\end{abstract}

Keywords : corporate governance, bank risk, intellectual capital

\section{PENDAHULUAN}

Latar Belakang Masalah. Intellectual capital (IC) merupakan salah satu indikator pengukuran aset tidak berwujud (intangible assets) yang menarik perhatian para ahli di berbagai bidang, termasuk akuntansi (Sugiarti, 2012). Perhatian para ahli di dunia terhadap intellectual capital telah dimulai sejak tahun 1990-an ketika praktek pengelolaan aset tidak berwujud dikaitkan dengan perkembangan teknologi informasi. Intellectual capital dalam perkembangannya dipergunakan sebagai salah satu ukuran penentuan nilai perusahaan, yang bertujuan untuk mengukur proses pengelolaan perusahaan berbasiskan pengetahuan (knowledge-based industries) dan sumber daya tak berwujud (intangible resources) (Hsu \& Shaberwal, 2011). Berbagai hasil penelitian dan literatur menunjukan bahwa perusahaan yang mampu bertahan lama, karena perusahaan tersebut menggunakan pengetahuan (knowledge) sebagai modal (Sangkala, 2006).

Pentingnya intellectual capital dalam suatu perusahaan ditunjang dengan adanya fenomena masih rendahnya kualitas sumber daya manusia dan sistem teknologi informasi yang dimiliki perusahaan perbankan di Indonesia. Tabel 1 menunjukkan biaya pengembangan sumber daya manusia dan pengembangan teknologi informasi lima bank besar di Indonesia. Jika dilihat dari prosentase rata-rata biaya pengembangan sumber daya manusia tahun 2017 hingga tahun 2019 dibanding rata-rata total biaya operasional tahun 2017 sampai 2019, biaya yang dikeluarkan bank-bank tersebut untuk pengembangan sumber daya manusia relatif besar. Namun, besarnya biaya yang dikeluarkan tidak sebanding dengan kualitas sumber daya manusia yang dimilikinya. Lemahnya sistem teknologi yang dimiliki 
Tabel 1

Rata-rata Biaya Pengembangan Sumber Daya Manusia (SDM) dan Biaya Pengembangan IT Bank Besar di Indonesia selama tahun 2017-2019 (dalam jutaan Rp)

\begin{tabular}{lccc}
\multicolumn{1}{c}{ Bank } & $\begin{array}{c}\text { Rata-rata Biaya } \\
\text { Pengembangan } \\
\text { SDM Tahun } \\
\text { 2017-2019 }\end{array}$ & $\begin{array}{c}\text { Rata-rata Biaya } \\
\text { Pengembangan IT } \\
\text { Tahun 2017-2019 }\end{array}$ & $\begin{array}{c}\text { Rata-rata Total } \\
\text { Biaya Operasional } \\
\text { Tahun 2017-2019 }\end{array}$ \\
\hline $\begin{array}{l}\text { PT. Bank Rakyat Indonesia } \\
\text { (Persero) Tbk. }\end{array}$ & $22,339,517$ & 208,038 & $41,799,186$ \\
\hline PT. Bank Mandiri (Persero) Tbk. & $16,134,152$ & $1,187,203$ & $37,552,018$ \\
\hline PT. Bank Central Asia, Tbk. & $12,271,842$ & $1,632,663$ & $27,861,361$ \\
\hline $\begin{array}{l}\text { PT. Bank Negara Indonesia } \\
\text { (Persero) Tbk. }\end{array}$ & $9,660,687$ & $1,139,772$ & $22,111,072$ \\
\hline $\begin{array}{l}\text { PT. Bank Tabungan Negara } \\
\text { (Persero) Tbk. }\end{array}$ & $2,764,982$ & 270,010 & $6,695,442$ \\
\hline
\end{tabular}

Sumber : data sekunder yang diolah (2020)

oleh perbankan di Indonesia dapat dilihat dari biaya pengembangan teknologi informasi yang dikeluarkan masih rendah. Sesuai dengan visi API (Arsitektur Perbankan Indonesia) yaitu mencapai suatu sistem perbankan yang sehat, kuat, dan efisien, pelaku perbankan harus segera berbenah. Pelaku perbankan harus mulai menyadari untuk dapat bertahan dalam persaingan, perlu meningkatkan kinerja intellectual capital-nya. Kinerja intellectual capital menurut Pulic (1998) adalah kemampuan intelektual suatu perusahaan yang menunjukkan gambaran padu mengenai modal fisik yang digunakan dan modal manusia.

Faktor yang dapat mempengaruhi kinerja intellectual capital (IC) antara lain corporate governance dan risiko bank. The Organization for Economic Cooperation and Development (OECD), 2004, mendefinisikan corporate governance (CG) sebagai sistem yang digunakan untuk mengarahkan dan mengontrol perusahaan. Risiko sendiri dapat diartikan sebagai kemungkinan untuk kehilangan, baik kehilangan secara keuangan maupun non keuangan sebagai hasil dari suatu aktivitas.

Penelitian mengenai kinerja intellectual capital telah banyak dilakukan, namun penelitian dalam bidang ini masih menarik perhatian untuk dilakukan. Hal ini disebabkan oleh ketidakkonsistenan dalam hasil penelitian. Penelitian ini mengacu pada penelitian yang telah dilakukan oleh I dan Hatane (2017), tentang determinan kinerja modal intelektual dengan capital structure sebagai variabel mediasi. Adapun variabel yang ditambahkan pada penelitian ini adalah risiko bank, karena masih adanya ketidakkonsistenan hasil penelitian pengaruh risiko bank terhadap kinerja intellectual capital.

Penelitian ini menggunakan sampel perusahaan perbankan yang terdaftar di Bursa Efek Indonesia (BEI) dari tahun 2017 sampai dengan tahun 2019. Perusahaan perbankan dipilih karena pada tahun-tahun tersebut bank sedang dalam persiapan berbenah untuk menghadapi persaingan pada Masyarakat Ekonomi ASEAN (MEA) di tahun 2020. Bank yang sedang dalam persiapan berbenah memerlukan pengkajian modal intelektual sebagai keunggulan kompetitif untuk mengetahui kekuatan bank itu sendiri. Selain itu, secara keseluruhan karyawan sektor perbankan "intellectually" lebih homogeny dibanding dengan sektor ekonomi lainnya (Kubo dan Saka, 2002 dalam Ulum, 2006).

\section{Tujuan Penelitian}

1. Untuk menguji secara empiris dan menganalisis pengaruh corporate governance terhadap capital structure. 
2. Untuk menguji secara empiris dan menganalisis pengaruh risiko bank terhadap capital structure.

3. Untuk menguji secara empiris dan menganalisis pengaruh corporate governance terhadap kinerja intellectual capital.

4. Untuk menguji secara empiris dan menganalisis pengaruh capital structure terhadap kinerja intellectual capital.

5. Untuk menguji secara empiris dan menganalisis pengaruh risiko bank terhadap kinerja intellectual capital.

6. Untuk menguji secara empiris dan menganalisis apakah capital structure dapat memediasi pengaruh corporate governance terhadap kinerja intellectual capital.

7. Untuk menguji secara empiris dan menganalisis apakah capital structure dapat memediasi pengaruh risiko bank terhadap kinerja intellectual capital.

\section{TINJAUAN TEORETIS}

Resourced Based Theory (RBT). Resourced Based Theory (RBT) kali pertama disampaikan oleh Wernefelt (1984) dalam artikel pionernya berjudul "A Resource based view of the firm" yang menggabungkan ide "distinctive competencies"e nya Selznick (1957) dan karya Penrose (1959) tentang "definition of the firm as a system of productive resources" (Nothnagel, dalam Ulum, 2006). RBT merupakan teori yang menggunakan pendekatan berbasis sumber daya dalam menganalisis keunggulan kompetitif yang dimiliki oleh perusahaan. RBT meyakini bahwa sebuah perusahaan akan memperoleh keunggulan kompetitif apabila memiliki sumber daya yang unggul.

Teori Pecking Order. Pecking order theory mengasumsikan tidak ada sasaran dalam menentukan struktur modal, tetapi perusahaan menyesuaikan kebijakan pembiayaannya untuk meminimalkan biaya yang terkait (Ritha, 2016). Pecking order theory mempunyai dua sinyal. Perusahaan dengan tingkat pertumbuhan yang tinggi cenderung menjaga dan mempertahankan rasio hutang pada level yang rendah (sinyal negatif) (Yusintha dan Suryandari, 2010). Perusahaan dengan tingkat pertumbuhan yang tinggi akan melakukan ekspansi dengan menggunakan hutang (sinyal positif) (Yusintha dan Suryandari, 2010).

Teori Trade Off. Teori trade off menjelaskan tentang adanya hubungan antara pajak, risiko kebangkrutan, dan penggunaan hutang yang disebabkan keputusan struktur modal yang diambil perusahaan (Brealey dan Myers, 1991). Teori ini merupakan keseimbangan antara keuntungan dan kerugian atas penggunaan hutang. Model trade off tidak dapat menentukan secara tepat struktur modal yang optimal karena sulit untuk menentukan secara tepat present value biaya financial distress dan present value agency cost.

Intellectual Capital (IC). Tom Stewart dalam artikelnya yang berjudul "Kekuatan Intelektual - Bagaimana Modal Intelektual Menjadi Aset Amerika yang Paling Berharga" mendefinisikan intellectual capital sebagai "seluruh pengetahuan yang diketahui semua sumber daya manusia di perusahaan yang memberikan keunggulan kompetitif di pasar". Menurut Alfathurahman (2018), intellectual capital merupakan sumber daya yang penting bagi perusahaan dan sebagai sesuatu yang tidak berwujud (intangible). Intellectual capital adalah konversi atas pengetahuan menjadi sesuatu yang menghasilkan nilai (I dan Hatane, 2017). Pada prakteknya modal intelektual adalah tentang sebuah aktivitas manajer yang dilakukan dalam upaya atas nama pengetahuan. Aktivitas-aktivitas tersebut berkaitan dengan pengembangan karyawan, res-trukturisasi organisasi, dan pengembangan aktivitas pemasaran (Ulum, 2015).

\section{Komponen Intellectual Capital}

Human Capital (HC). Human capital merupakan lifeblood dalam intellectual capital karena disinilah sumber innovation dan improvement walaupun komponen ini sulit untuk diukur (Sawarjuwono dan Kadir, 2003). HC meliputi sumber daya manusia 
yang dimiliki organisasi dan sumber daya yang berada di luar organisasi (eksternal), seperti konsumen dan pemasok.

Menurut Widaryanti (2011), human capital mencerminkan kemampuan kolektif perusahaan untuk menghasilkan solusi terbaik berdasarkan pengetahuan yang dimiliki oleh orang-orang yang ada dalam perusahaan tersebut.

Organizational Capital atau Structural Capital (SC). Structural capital (SC) merupakan kemampuan organisasi atau perusahaan dalam memenuhi proses rutinitas perusahaan dan strukturnya yang mendukung usaha karyawan untuk menghasilkan kinerja intelektual yang optimal serta kinerja bisnis secara keseluruhan (Widaryanti, 2011). SC berfokus pada segala hal seperti software, jaringan distribusi, dan supplay chain. Termasuk dalam hal ini adalah database, organizational charts, process manuals, strategies, routines, dan segala hal yang membuat nilai perusahaan lebih besar daripada nilai materialnya (Ulum, 2015).

Relational Capital atau Customer Capital (CC). Customer Capital (CC) merupakan hubungan yang harmonis/ association network yang dimiliki oleh perusahaan dengan para mitranya (Widaryanti, 2011). Customer capital dapat berasal dari para pemasok yang andal dan berkualitas, pelanggan yang loyal dan merasa puas akan pelayanan perusahaan yang bersangkutan, serta hubungan perusahaan dengan pemerintah maupun dengan masyarakat sekitar. Customer capital mencakup external revenue yang menghasilkan nilai bagi perusahaan seperti branding, reputasi, aliansi strategis, hubungan dengan konsumen, dan pemasok (Tan et al., 2007).

Modified Value Added Intellectual Capital (MVAIC). Metode Value Added Intellectual Coefficient (VAIC ${ }^{\mathrm{TM}}$ ) dikembangkan oleh Pulic pada tahun 1997 yang didesain untuk menyajikan informasi tentang value creation efficiency dari aset berwujud dan aset tidak berwujud yang dimiliki perusahaan (Ulum, 2015). Pada perkembangannya, VAIC ${ }^{\mathrm{TM}}$ mengalami modifikasi dalam mengukur kinerja intellectual capital menjadi modified value added intellectual coefficient (MVAIC). Pengukuran intellectual capital dengan menggunakan MVAIC dimulai dengan mengukur value added (VA). VA diukur dengan formula awal dari Pulic (2000) yaitu VA = OUT - IN (Ulum, 2017). OUT merupakan total penjualan serta pendapatan lain, IN merupakan total biaya yang dikeluarkan perusahaan kecuali beban karyawan.

Corporate Governance (CG). The Organization for Economic Cooperation and Development (OECD), 2004, mendefinisikan corporate governance (CG) sebagai sistem yang digunakan untuk mengarahkan dan mengontrol perusahaan. Menurut Forum for Corporate Governance in Indonesia (FCGI), 2014, corporate governance merupakan seperangkat peraturan yang menetapkan hubungan antara pemegang saham, pengurus, pihak kreditur, pemerintah, karyawan, dan para pemegang kepentingan intern dan ekstern lainnya sehubungan dengan hak-hak dan kewajiban mereka.

Risiko Bank. Industri perbankan dideskripsikan sebagai industri yang paling berisiko karena bank lebih tinggi pengungkapannya daripada perusahaan di industri lain (Musalli dan Ismail, 2012). Risiko menurut El-Bannany (2008) adalah potensi kerugian yang meningkat dari berbagai sumber, misalnya risiko transaksi, risiko pemindahan, atau risiko ekonomi. Risiko berarti kemungkinan untuk kehilangan, baik kehilangan secara keuangan maupun non keuangan, seperti risiko kredit, risiko pasar, dan risiko operasional (Musalli dan Ismail, 2012).

Capital Structure. Capital structure adalah kombinasi dari hutang dan modal dalam perusahaan yang digunakan untuk membiayai aktivanya (Bayunitri dan Malik, 2015). Capital structure merupakan kombinasi dari hutang jangka panjang dan modal yang dipertahankan oleh perusahaan dimana struktur modal tersebut secara signifikan dapat mempengaruhi nilai perusahaan melalui tingkat pengembalian dan risiko yang dimilikinya (I dan Hatane, 2017). 


\section{Hipotesis}

Pengaruh Corporate Governance Terhadap Capital Structure. Pertumbuhan bank yang tinggi karena pelaksanaan corporate governance yang baik akan mendorong manajemen untuk terus melakukan ekspansi. Sesuai dengan pecking order theory, perusahaan dengan tingkat pertumbuhan yang tinggi akan melakukan ekspansi dengan menggunakan hutang (sinyal positif) untuk mengembangkan usahanya (Yusintha dan Suryandari, 2010). Bank yang semakin bertumbuh cenderung lebih mudah dalam memperoleh pinjaman dari luar. Pemberi pinjaman akan merasa lebih percaya ketika rasio bank menunjukkan kondisi sehat. Jadi, semakin baik corporate governance suatu perusahaan akan semakin baik juga capital structure yang dimilikinya. Seperti penelitian yang dilakukan oleh Putri \& Zulvia (2019) bahwa corporate governance yang diproksikan dengan kepemilikan institusional berpengaruh positif terhadap capital structure. Berdasarkan uraian di atas, maka hipotesis yang diajukan adalah sebagai berikut:

$\mathrm{H}_{1}$ : Corporate Governance (CG) berpengaruh positif terhadap capital structure.

Pengaruh Risiko Bank Terhadap Capital Structure. Patton dan Zelenka (1997, p.11) dalam El-Bannany (2008) menyatakan bahwa persentasi dari intangible asset merupakan proksi dari performa masa depan perusahaan tergantung dari aset yang berisiko. Sesuai dengan trade off theory, aktiva yang tidak berwujud (intangible assets) akan kehilangan banyak nilai jika terjadi financial distress. Perusahaan yang menggunakan aktiva semacam ini seharusnya menggunakan sedikit hutang karena tingkat risiko yang tinggi.

Semakin tinggi risiko yang dimiliki perusahaan perbankan, semakin berhati-hati perusahaan tersebut dalam menetapkan struktur modalnya. Perusahaan dengan risiko bisnis yang tinggi cenderung menggunakan hutang yang rendah, begitu juga sebaliknya perusahaan dengan risiko bisnis yang rendah cenderung menggunakan hutang yang lebih tinggi (I dan Hatane, 2017). Seperti penelitian yang dilakukan oleh Ritha (2016). Berdasarkan uraian di atas, maka hipotesis yang diajukan adalah sebagai berikut:

$\mathrm{H}_{2}$ : Risiko bank berpengaruh negatif terhadap capital structure.

\section{Pengaruh Corporate Governance} Terhadap Kinerja Intellectual Capital. Bank yang telah menjalankan CG dengan baik diharapkan dapat menghasilkan sumber daya yang unggul yang dapat menjadi keunggulan kompetitif bagi perusahaan. Sesuai dengan resourced based theory (RBT), resources yang berharga dan langka dapat diarahkan untuk menciptakan keunggulan bersaing, sehingga resources yang dimiliki mampu bertahan lama dan tidak mudah ditiru, ditransfer atau digantikan (Ulum, 2006). Seperti penelitian yang dilakukan oleh Oktavian dan Ahmar (2019), Supradnya, Putri, dan Ulupui (2016), serta Mahmudi dan Nurhayati (2014) bahwa corporate governance yang diproksikan dengan kompetensi dewan komisaris, proporsi komisaris independen, dan ukuran komite audit berpengaruh positif terhadap capital structure. Berdasarkan uraian di atas, maka hipotesis yang diajukan adalah sebagai berikut :

$\mathrm{H}_{3}$ : Corporate Governance (CG) berpengaruh positif terhadap kinerja intellectual capital.

Pengaruh Capital Structure terhadap Kinerja Intellectual Capital. Capital structure merupakan kombinasi dari hutang jangka panjang dan modal yang dipertahankan oleh perusahaan dimana struktur modal tersebut secara signifikan dapat mempengaruhi nilai perusahaan melalui tingkat pengembalian dan risiko yang dimilikinya (I dan Hatane, 2017). Bank akan cenderung menggunakan hutang daripada modal untuk mendanai pengembangan modal intelektualnya. Hasil penelitian terdahulu menunjukkan bahwa capital structure berpengaruh positif terhadap kinerja intellectual capital (Rashid, Ibrahim, Othman dan See, 2012; Garc1'a- dan Martı'nez, 2005; dan Williams, 2001). Berdasarkan uraian di atas, maka hipotesis yang diajukan adalah 
sebagai berikut:

$$
\begin{aligned}
\mathrm{H}_{4} \quad \text { : Capital structure berpengaruh } \\
\text { positif terhadap kinerja intellectual } \\
\text { capital. }
\end{aligned}
$$

Pengaruh Risiko Bank Terhadap Kinerja Intellectual Capital. Menurut Patton dan Zelenka (1997) dalam El-Bannany (2008) menyatakan bahwa persentase aset tidak berwujud merupakan proksi dari kinerja masa depan perusahaan yang tergantung pada risiko aset. Bank yang memiliki risiko tinggi artinya bank tersebut memiliki aset tidak berwujud dalam jumlah besar. Jumlah aset tidak berwujud yang besar yang tercermin dalam risiko bank dapat menjadikannya sebagai keunggulan kompetitif. Hal ini membantu bank untuk memberikan kemudahan serta pelayanan yang lebih baik bagi pelanggan. Dengan pelayanan yang lebih baik, pelanggan akan merasa puas dan akan loyal pada perusahaan dan meningkatkan citra positif dari perusahaan. Seperti penelitian yang dilakukan oleh ElBannany (2008); Musalli dan Ismail (2012); serta Sefidgar, Maleki, dan Minouei (2015) bahwa risiko bank berpengaruh positif terhadap kinerja intellectual capital. Berdasarkan uraian di atas, maka hipotesis yang diajukan adalah sebagai berikut:

H5 : Risiko bank berpengaruh positif terhadap kinerja intellectual capital.

Pengaruh Corporate Governance terhadap Kinerja Intellectual Capital dengan Capital Structure sebagai Variabel Mediasi. Bank yang telah menjalankan operasinya sesuai dengan prosedur yang ditetapkan dalam Pedoman Umum Good Corporate Governance diharapkan dapat menciptakan kondisi kerja yang sesuai dengan lingkup tujuan bank dan etika kerja. Bank yang sehat cenderung lebih mudah dalam memperoleh pinjaman dari luar. Semakin baik pelaksanaan CG dalam suatu bank, semakin mudah pula bank tersebut dalam memperoleh pinjaman dari luar. Peningkatan kualitas pengelolaan CG dapat memberikan kontribusi pada peningkatan capital strucutre-nya.

Hasil penelitian terdahulu me-nunjukkan bahwa corporate governance ber-pengaruh positif terhadap capital structure (Putri \& Zulvia, 2019; Kusumo dan Hadiprajitno, 2017; serta Kurniawan dan Rahardjo, 2014). Capital structure ber-pengaruh positif terhadap kinerja intellectual capital (Rashid, Ibrahim, Othman dan See, 2012; Garci'adan Martı'nez, 2005; dan Williams, 2001). Berdasarkan uraian di atas, maka hipotesis yang diajukan adalah sebagai berikut:

$\mathrm{H}_{6}$ : Corporate governance berpengaruh positif terhadap kinerja intellectual capital dengan capital structure sebagai variabel mediasi.

\section{Pengaruh Risiko Bank Terhadap} Kinerja Intellectual Capital dengan Capital Structure sebagai Variabel Mediasi. Patton dan Zelenka (1997, p.11) dalam El-Bannany (2008) menyatakan bahwa persentasi dari intangible asset merupakan proksi dari performa masa depan perusahaan tergantung dari aset yang berisiko. Semakin tingginya risiko bank yang diproksikan oleh aset tidak berwujud yang dimilikinya, kreditur berharap bisa mendapatkan pengembalian atas hutang yang diberikan semakin banyak.

Hasil penelitian terdahulu me-nunjukkan bahwa risiko bank berpengaruh negatif terhadap capital structure (Ritha 2016, Wiagustini dan Pertamawati 2015, sert Bayunitri dan Malik 2015). Capital structure berpengaruh positif terhadap kinerja intellectual capital (Rashid, Ibrahim, Othman dan See, 2012; Garc1'a dan Martı'nez, 2005; dan Williams, 2001). Berdasarkan uraian di atas, maka hipotesis yang diajukan adalah sebagai berikut

$\mathrm{H}_{7}$ : Risiko bank berpengaruh positif terhadap kinerja intellectual capital dengan capital structure sebagai variabel mediasi 


\section{Gambar 1}

Kerangka Penelitian

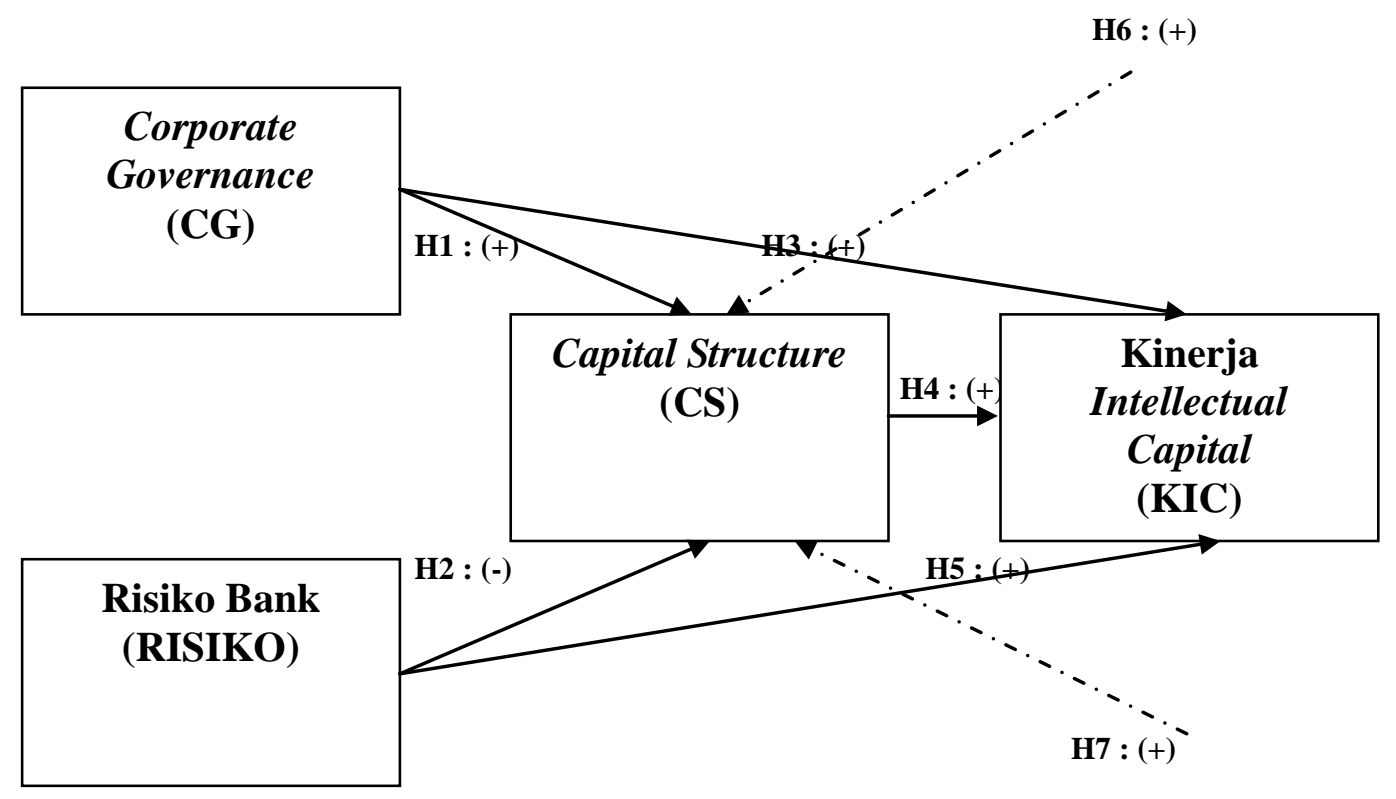

\section{METODE PENELITIAN}

Populasi dan Teknik Pengambilan Sampel. Populasi penelitian ini adalah perusahaan perbankan yang terdaftar di Bursa Efek Indonesia (BEI) sebanyak 45 perusahaan dengan kurun waktu pengamatan tahun 2017-2019 atau 3 tahun, sehingga jumlah anggota populasi yang diamati sebanyak 135 perusahaan. Sampel dalam penelitian ini sebanyak 120 perusahaan perbankan yang terdaftar di Bursa Efek Indonesia tahun 2017-2019. Pemilihan sampel dalam penelitian ini menggunakan metode purposive sampling dengan tujuan agar sampel yang dipilih dapat representative.

Variabel Penelitian dan Definisi Operasionalnya. Kinerja Intellectual Capital. MVAIC merupakan model pengukuran kinerja intellectual capital yang berbasis pada model dari Pulic, yaitu VAIC $^{\text {TM }}$ (Ulum, 2017).

$$
\mathbf{V A}=\mathbf{O U T}-\mathbf{I N}
$$

Sumber : Pulic (1998)

VA = value added
OUT = pendapatan

$\mathrm{EC}=$ beban

Intellectual Capital Effieciency (ICE). Menurut Pulic dalam Ulum (2017), VAIC ${ }^{\mathrm{TM}}$ merupakan hasil penjumlahan dari intellectual capital efficiency (ICE) dan capital employeed efficiency (CEE), sementara ICE adalah HCE (human capital efficiency) ditambah structural capital efficiency (SCE) (Ulum, 2017).

$$
\begin{aligned}
& \mathrm{ICE}=\mathrm{HCE}+\mathrm{SCE}+\mathrm{RCE} \\
& \mathrm{HCE}=\frac{V A}{H C}, \mathrm{SCE}=\frac{S C}{V A}, \mathrm{RCE}=\frac{R C}{V A}
\end{aligned}
$$

Sumber : Pulic (1998)

$$
\begin{aligned}
\mathrm{HC}= & \begin{array}{l}
\text { human capital } \\
\text { kompensasi dan } \\
\text { karyawan) }
\end{array}
\end{aligned}
$$

$\mathrm{SC}=$ structural capital $(\mathrm{VA}-\mathrm{HC})$

$\mathrm{RC}=$ relational capital (biaya pemasaran)

Capital Employeed Efficiency (CEE). Capital employed efficiency adalah sebuah indikator yang akan menunjukkan seberapa banyak nilai tambah (value added) yang tercipta atas setiap unit moneter yang dihabiskan untuk sumber daya fisik (Trinita dan Dewi, 2019). 


$$
\mathrm{CEE}=\frac{V A}{C E}
$$

Sumber : Pulic (1998)

$$
\begin{gathered}
\mathrm{CE}=\underset{\text { capital employed (nilai buku }}{ } \\
\text { total aset) }
\end{gathered}
$$

Modified Value Added Intellectual Capital (MVAIC). Rasio terakhir adalah menghitung kemampuan-kemampuan intelektual perusahaan dengan menjumlahkan koefisien-koefisien yang telah dihitung sebelumnya. Secara utuh, MVAIC diformulasikan sebagai berikut (Ulum, 2017):

$$
\text { MVAIC }=\text { ICE }+ \text { CEE }
$$

Sumber : Pulic (1998)

\section{Corporate Governance. The} Organization for Economic Cooperation and Development (OECD), 2004, mendefinisikan corporate governance (CG) sebagai sistem yang digunakan untuk mengarahkan dan mengontrol perusahaan. Sesuai dengan Peraturan Bank Indonesia No. 8/14/PBI/2006 tanggal 5 Oktober 2006, dan Surat Edaran Bank Indonesia No. 15/15/DPNP tanggal 29 April 2013 Perihal Pelaksanaan Good Corporate Governance bagi Bank Umum, perbankan diharuskan melaksanakan Laporan Penilaian Sendiri (self assessment) Pelaksanaan GCG. Pelaksanaan self assessment dilakukan dengan checklist tingkat kepatuhan bank yang hasilnya dalam bentuk indeks bernama nilai komposit. Nilai komposit ini nantinya yang akan menentukan apakah kondisi pelaksanaan tata kelola bank dalam kelompok sangat baik, baik, cukup baik, kurang baik, atau tidak baik.

Risiko Bank. Risiko berarti kemungkinan untuk kehilangan, baik kehilangan secara keuangan maupun non keuangan (Musalli dan Ismail, 2012). Persentase dari intangible aset merupakan indeks yang paling relevan dalam mempengaruhi kinerja masa depan dari perusahaan dan aset yang berisiko (Paton dan Zelenka, 1997 dalam Sefidgar, Maleki, dan Minouei, 2014).

$$
\begin{aligned}
& \text { Risiko Bank = } \\
& \text { aset tak berwujud } \\
& \text { total aset bank ipada tahunt }
\end{aligned}
$$

Sumber : Sefidgar, Maleki, dan Minouei (2014)

Capital Structure. Capital structure adalah kombinasi dari hutang dan modal dalam perusahaan yang digunakan untuk membiayai aktivanya (Bayunitri dan Malik, 2015). Leverage digunakan sebagai proksi capital structure. Rumus menghitung leverage adalah sebagai berikut (I dan Hatane, 2017) :

\begin{tabular}{c}
$\begin{array}{c}\text { Leverage }= \\
\text { total hutang (nilai buku) }\end{array}$ \\
\hline total hutang (nilai buku) + total modal (nilai pasar) \\
\hline
\end{tabular}

Tabel 2

Penilaian Self Assesment Corporate Governance

\begin{tabular}{cc}
\hline Nilai Komposit & Prediksi \\
\hline Nilai komposit $<1,5$ & Sangat Baik \\
$1,5 \leq$ nilai komposit $<2,5$ & Baik \\
$2,5 \leq$ nilai komposit $<3,5$ & Cukup Baik \\
$3,5 \leq$ nilai komposit $<4,5$ & Kurang Baik \\
Nilai komposit $>4,5$ & Tidak Baik \\
\hline
\end{tabular}

Sumber: SK BI No. 9/12/DPNP 
Teknik Analisis. Metode analisis data yang digunakan dalam penelitian ini menggunakan metode analisis kuantitatif dengan alat analisis statistika yang didukung dengan aplikasi statistical package for social science (SPSS) versi 25.0. Teknik analisis data yang digunakan dalam penelitian ini adalah analisis regresi linear berganda dan path analysis. Analisis regresi linear berganda digunakan untuk menguji hubungan antara satu variabel dependen dengan dua atau lebih variabel independen. Sedangkan path analysis digunakan untuk menghubungkan variabel pengganggu yang dapat memediasi atau tidak antara variabel independen dan variabel dependen. Data diuji terlebih dahulu menggunakan uji asumsi klasik.

Analisis Regresi Linier Berganda. Untuk mengetahui pengaruh antara variabel terikat (KIC) dengan variabel bebas (CG dan Risiko) maka digunakan persamaan regresi linier berganda sebagai berikut:

$\mathrm{CS}=\alpha_{1}+\beta_{1} \mathrm{CG}+\beta_{2}$ Risiko $+e_{1}$

$\mathrm{KIC}=\alpha_{2}+\beta_{3} \mathrm{CG}+\beta_{4} \mathrm{CS}+\beta_{5}$ Risiko $+\mathrm{e}_{2}$

Keterangan :

$$
\begin{array}{ll}
\text { CG } & =\text { Corporate Governance }(C G) \\
\text { Risiko } & =\text { Risiko Bank } \\
\text { KIC } & =\text { Kinerja Intellectual Capital } \\
\text { CS } & =\text { Capital Structure }
\end{array}
$$$$
\beta_{1}, \beta_{2}, \beta_{3}, \beta_{4}, \beta_{5}=\text { Koefisien regresi }
$$

Analisis Jalur Path (Uji Sobel). Metode analisis jalur (path analysis) digunakan untuk menguji pengaruh variabel intervening. Analisis jalur merupakan perluasan dari analisis regresi berganda, atau analisis jalur adalah penggunaan analisis regresi untuk menaksir hubungan kasualitas antar variabel (model casual) yang telah ditetapkan sebelumnya berdasarkan teori. Menurut Ghozali (2018) pengujian hipotesis dalam mediasi dapat dilakukan dengan melakukan prosedur yang dikembangkan oleh Sobel pada tahun 1982 dan dikenal dengan uji Sobel (Sobel test).

\section{HASIL DAN PEMBAHASAN}

Gambaran Umum Objek Penelitian. Populasi yang digunakan dalam penelitian ini adalah perusahaan perbankan go public yang melaporkan laporan keuangannya di Bursa Efek Indonesia dari tahun 2017 hingga tahun 2019. Sampel penelitian sebanyak 120 perusahaan perbankan yang terdaftar di BEI, dimana proses pengambilan sampel dilakukan menggunakan metode purposive sampling yang dipilih berdasarkan kriteriakriteria tertentu. Tabel 4 menunjukkan ikhtisar pemilihan sampel penelitian.

Berdasarkan tabel 5 dan 6 tersebut dapat dilihat bahwa besarnya nilai Kolmogorov adalah 0,000 dan 0,000 dengan nilai signifikan 0,216 dan 0,247 . Hal ini berarti data terdistribusi tidak normal karena nilai signifikansinya kurang dari 0,05 sehingga model regresi tidak memenuhi

asumsi normalitas. Setelah data-data outlier dibuang, dihasilkan 91 data penelitian dan dilakukan pengujian kembali atas data penelitian tersebut. Hasil dari pengujian tersebut adalah sebagai berikut :

Deskripsi Hasil Penelitian. Hasil penelitian yang disajikan dalam penelitian ini merupakan data sekunder yang diolah dengan menggunakan aplikasi software statistical package for social science (SPSS) versi 25.0.

Berdasarkan tabel $13 \mathrm{di}$ atas, model persa maan regresi yang dapat dituliskan adalah sebagai berikut :

\section{$\mathrm{CS}=$ 0,460 + 0,003 CG + 0,194 Risiko + e}

Persamaan regresi tersebut dapat dijelaskan sebagai berikut :

a. Koefisien regresi b1 $(\mathrm{CG})=0,003$ menyatakan bahwa variabel corporate governance mempunyai tanda positif terhadap capital structure.

b. Koefisien regresi b2 (Risiko) $=0,194$ menyatakan bahwa variabel risiko bank mempunyai tanda positif terhadap capital structure, yang berarti bahwa peningkatan terhadap risiko bank akan dapat berpotensi capital structure. 
Tabel 3

Hasil Analisis Regresi Linier Berganda Variabel Dependen Capital Structure

\begin{tabular}{|c|c|c|c|c|c|c|}
\hline & \multirow[t]{3}{*}{ Model } & \multirow{2}{*}{\multicolumn{2}{|c|}{$\begin{array}{c}\text { Unstandardized } \\
\text { Coefficients }\end{array}$}} & \multirow{3}{*}{$\begin{array}{l}\text { Standardized } \\
\text { Coefficients } \\
\text { Beta }\end{array}$} & \multirow[t]{3}{*}{$\mathrm{T}$} & \multirow[t]{3}{*}{ Sig. } \\
\hline & & & & & & \\
\hline & & B & Std. Error & & & \\
\hline \multirow[t]{3}{*}{1} & (Constant) & .460 & .040 & & 11.517 & .000 \\
\hline & CG & .003 & .008 & .030 & 417 & .677 \\
\hline & RISIKO & .194 & .019 & .734 & 10.156 & .000 \\
\hline
\end{tabular}

a. Dependent Variable: CS

Sumber: Data sekunder yang diolah (2020)

Tabel 4

Hasil Analisis Regresi Linier Berganda Variabel Dependen Kinerja Intellectual Capital

\begin{tabular}{ccccccc}
\hline \multirow{2}{*}{ Model } & \multicolumn{2}{c}{$\begin{array}{c}\text { Unstandardized } \\
\text { Coefficients }\end{array}$} & $\begin{array}{c}\text { Standardized } \\
\text { Coefficients }\end{array}$ & T & Sig. \\
\cline { 3 - 5 } & & B & Std. & Beta & & \\
\cline { 3 - 5 } & & Error & & -12.975 & .000 \\
\hline 1 & (Constant) & -9.409 & .725 & & .002 & .999 \\
& CG & .000 & .089 & .000 & 14.444 & .000 \\
& RISIKO & 4.668 & .323 & .820 & 2.595 & .011 \\
\hline
\end{tabular}

a. Dependent Variable: KIC

Sumber: Data sekunder yang diolah (2020

Berdasarkan tabel 4 model persamaan regresi yang dapat dituliskan adalah sebagai berikut :

KIC $=-9,409+0,000$ CG + 4,668 Risiko + $3,171 \mathrm{CS}+\mathrm{e}$

Persamaan regresi tersebut dapat dijelaskan sebagai berikut :

a. Koefisien regresi b3 $(\mathrm{CG})=0,000$ menyatakan bahwa variabel corporate governance mempunyai tanda positif terhadap kinerja intellectual capital.

b. Koefisien regresi b4 (Risiko) $=4,668$ menyatakan bahwa variabel risiko bank mempunyai tanda positif terhadap perilaku manajemen keuangan, yang berarti bahwa peningkatan terhadap risiko bank akan dapat berpotensi kinerja intellectual capital.

c. Koefisien regresi b5 $(\mathrm{CS})=3,171$ menyatakan bahwa variabel capital structure mempunyai tanda positif terhadap kinerja intellectual capital, yang berarti bahwa peningkatan terhadap capital structure akan dapat berpotensi meningkatkan kinerja intellectual capital.

Pengujian Hipotesis dan Pembahasan. Pengaruh Corporate Governance terhadap
Capital Structure. Hasil pengujian diperoleh nilai signifikansi untuk variabel corporate governance menunjukkan nilai t hitung 0,417 dengan nilai signifikansi sebesar 0,677 > 0,05 . Hasil penelitian tersebut menunjukkan bahwa Ho diterima dan Ha ditolak. Dengan demikian diperoleh bahwa hipotesis yang menyatakan bahwa corporate governance memiliki pengaruh positif yang signifikan terhadap kinerja intellectual capital ditolak.

Pengujian hipotesis pertama tersebut menunjukkan bahwa corporate governance yang diproksikan dengan nilai komposit self assesment sudah mencakup banyak aspek. Namun dalam pelaksanaan pemberian hutang kepada bank, pengambil kebijakan tidak mempertimbangkan aspek-aspek yang ada dalam corporate governance. Penelitian ini juga didukung oleh penelitian yang dilakukan oleh Putri dan Zulvia (2019) yang menggunakan proksi komite audit, Kusumo dan Hadiprajitno (2017) yang menggunakan proksi kepemilikan institusional dan kepemilikan manajerial, serta Ritha (2016) yang menggunakan proksi struktur 
kepemilikan. Penelitian Putri dan Zulvia (2019), Kusumo dan Hadiprajitno (2017), serta Ritha (2016) menunjukkan bahwa corporate governance tidak berpengaruh terhadap kinerja intellectual capital structure.

Pengaruh Risiko Bank terhadap Capital Structure. Hasil pengujian untuk variabel risiko bank menunjukkan nilai $t$ hitung 10,156 dan nilai signifikansi sebesar $0,000<0,05$ dengan koefisien regresi bertanda positif. Dengan demikian diperoleh hasil yang menyatakan bahwa risiko bank berpengaruh positif terhadap capital structure. Hasil penelitian tersebut menunjukkan bahwa hipotesis kedua yang menyatakan bahwa risiko bank berpengaruh negatif terhadap capital structure ditolak. Hal ini bisa membuat bank memperoleh laba yang lebih tinggi, sehingga menarik kreditur untuk memberikan pinjaman kepadanya. Hasil penelitian ini didukung oleh penelitian yang dilakukan oleh I dan Hatane (2017) serta Kellen (2010), yang menunjukkan risiko bank berpengaruh positif terhadap capital structure.

Pengaruh Corporate Governance terhadap Kinerja Intellectual Capital. Hasil pengujian diperoleh nilai signifikansi untuk variabel corporate governance menunjukkan nilai t hitung 0,002 dengan nilai signifikansi sebesar 0,999 > 0,05. Hasil penelitian tersebut menunjukkan bahwa Ho diterima dan Ha ditolak. Dengan demikian diperoleh bahwa hipotesis yang menyatakan bahwa corporate governance memiliki pengaruh positif yang signifikan terhadap kinerja intellectual capital ditolak.

Pengujian hipotesis ketiga tersebut menunjukkan bahwa corporate governance yang diproksikan dengan nilai komposit self assesment sudah mencakup banyak aspek. Namun dalam pelaksanaan penilaian nilai komposit ini bank melakukan self assessment atau menilai diri sendiri. Hal ini disebabkan jika bank memberikan nilai yang tidak wajar maka Otoritas Jasa Keuangan (OJK) akan meminta bank untuk merevisi laporan tata kelola perusahaannya. Hasil penelitian ini menunjukkan bahwa corporate governance tidak berpengaruh terhadap kinerja intellectual capital. Penelitian ini juga didukung oleh penelitian yang dilakukan oleh Oktavian dan Ahmar (2019), I dan Hatane (2017), serta Supradnya, Putri, dan Ulupui (2016) yang menunjukkan bahwa corporate governance tidak berpengaruh terhadap kinerja intellectual capital structure.

\section{Pengaruh Capital Structure terhadap} Kinerja Intellectual Capital. Hasil pengujian diperoleh nilai $t$ hitung untuk variabel capital structure menunjukkan nilai $\mathrm{t}$ hitung $=2,595$ dengan nilai signifikansi sebesar $0,011<0,05$. Hasil penelitian tersebut menunjukkan bahwa Ho tidak dapat diterima dan Ha tidak dapat ditolak. Karena nilai $\mathrm{t}$ hitung (koefisien) bernilai positif, maka dapat disimpulkan bahwa hasil penelitian berpengaruh positif. Dengan demikian diperoleh bahwa hipotesis yang menyatakan bahwa capital structure memiliki pengaruh positif yang signifikan terhadap kinerja intellectual capital diterima.

Pengujian hipotesis keempat menunjukkan capital structure memiliki pengaruh positif yang signifikan terhadap kinerja intellectual capital. Semakin tinggi rasio capital structure yang dimiliki bank, dapat diartikan bahwa bank tersebut dalam komposisi struktur modalnya lebih banyak menggunakan hutang daripada modal sendiri. Bank akan cenderung menggunakan hutang daripada modal untuk mendanai pengembangan modal intelektualnya. Penelitian ini juga didukung oleh penelitian yang dilakukan oleh Rashid, Ibrahim, Othman dan See, 2012; Garc1'a- dan Mart1'nez, 2005; dan Williams, 2001.

\section{Pengaruh Risiko Bank terhadap} Kinerja Intellectual Capital. Hasil pengujian untuk variabel risiko bank menunjukkan nilai $\mathrm{t}$ hitung 14,444 dan nilai signifikansi sebesar $0,000<0,05$ dengan koefisien regresi bertanda positif. Dengan demikian diperoleh hasil yang menyatakan bahwa risiko bank berpengaruh positif terhadap kinerja intellectual capital. Hasil penelitian tersebut menunjukkan bahwa hipotesis kelima yang menyatakan bahwa risiko bank berpengaruh 
positif terhadap kinerja intellectual capital diterima.

Pengujian hipotesis kelima menunjukkan bahwa risiko bank berpengaruh positif terhadap kinerja intellctual capital . Hal ini dikarenakan peningkatan aset tidak berwujud yang dimiliki bank akan berdampak pula pada peningkatan risiko bank. Bank yang memiliki risiko tinggi artinya bank tersebut memiliki aset tidak berwujud dalam jumlah besar.

Apabila bank dapat terus menerus mempertahankan aset tak berwujudnya maka akan meningkatkan kinerja intellectual capital nya. Hasil penelitian ini didukung oleh penelitian yang dilakukan oleh ElBannany (2008); Musalli dan Ismail (2012); serta Sefidgar, Maleki, dan Minouei (2015) yang menyatakan bahwa risiko bank berpengaruh positif terhadap kinerja intellectual capital.

Pengaruh Corporate Governance terhadap Kinerja Intellectual Capital dengan Capital Structure sebagai Variabel Mediasi. Hasil pengujian Sobel Test diperoleh nilai statistik untuk variabel corporate governance menunjukkan nilai $0,37114454<1,98$. Hasil penelitian tersebut menunjukkan bahwa Ho diterima dan $\mathrm{Ha}$ ditolak. Dengan demikian diperoleh bahwa hipotesis yang menyatakan bahwa corporate governance memiliki pengaruh positif yang signifikan terhadap kinerja intellectual capital dengan capital structure sebagai variabel mediasi ditolak.

Pengujian hipotesis keenam menunjukkan bahwa corporate governance memiliki pengaruh positif yang signifikan terhadap kinerja intellectual capital dengan capital structure sebagai variabel mediasi ditolak. Hal ini dikarenakan dalam pelaksanaan penilaian nilai komposit ini bank melakukan self assessment atau menilai diri sendiri. Ketika bank menilai tata kelolanya sendiri, bank akan cenderung memberikan nilai yang tidak terlalu baik ataupun tidak terlalu buruk. Biasanya bank akan cenderung memberikan peringkat 2 untuk dirinya sendiri. Hasil penelitian ini didukung oleh penelitian yang dilakukan Putri dan Zulvia (2019) serta
Kusumo dan Hadiprajitno (2017) yang menyatakan bahwa corporate governance tidak berpengaruh terhadap capital structure.

\section{Pengaruh Risiko Bank terhadap} Kinerja Intellectual Capital dengan Capital Structure sebagai Variabel Mediasi. Hasil pengujian Sobel Test diperoleh nilai statistik untuk variabel risiko bank menunjukkan nilai $2,51497801>1,98$. Hasil penelitian tersebut menunjukkan bahwa Ho ditolak dan $\mathrm{Ha}$ diterima. Dengan demikian diperoleh bahwa hipotesis yang menyatakan bahwa risiko bank memiliki pengaruh positif yang signifikan terhadap kinerja intellectual capital dengan capital structure sebagai variabel mediasi diterima.

Pengujian hipotesis ketujuh menunjukkan bahwa risiko bank memiliki pengaruh positif yang signifikan terhadap kinerja intellectual capital dengan capital structure sebagai variabel mediasi diterima.

Hal tersebut mengakibatkan risiko bank memiliki hubungan yang positif dengan kinerja intellectual capital dengan dimediasi capital structure. Hasil penelitian ini sesuai dengan penelitian yang dilakukan Ritha (2016) serta Bayunitri dan Malik (2015) yang menyatakan bahwa risiko bank berpengaruh negatif terhadap capital structure. Penelitian ini juga didukung oleh penelitian yang dilakukan oleh Rashid, Ibrahim, Othman dan See (2012), Garc1'adan Martı'nez (2005), dan Williams, (2001) yang menyatakan bahwa capital structure berpengaruh positif terhadap intellectual capital.

\section{SIMPULAN}

Kesimpulan. Penelitian ini bertujuan untuk membuktikan pengaruh corporate governance dan risiko bank terhadap kinerja intellectual capital melalui capital structure sebagai variabel mediasi pada perusahaan perbankan yang terdaftar di Bursa Efek Indonesia periode 2017-2019. Hasilnya menunjukkan bahwa corporate governance tidak berpengaruh terhadap capital structure, sehingga $\mathrm{H}_{1}$ ditolak. Hasil penelitian ini menunjukkan risiko bank berpengaruh positif 
terhadap kinerja intellectual capital, sehingga $\mathrm{H}_{2}$ yang menyatakan risiko bank berpengaruh negatif terhadap kinerja intellectual capital ditolak. Hasil penelitian menyatakan bahwa corporate governance tidak berpengaruh terhadap kinerja intellectual capital, sehingga $\mathrm{H}_{3}$ ditolak.

Penelitian menemukan bahwa capital structure berpengaruh positif signifikan terhadap kinerja intellectual capital, sehingga $\mathrm{H}_{4}$ diterima. Hasil penelitian menemukan bahwa risiko bank berpengaruh positif signifikan terhadap kinerja intellectual capital, sehingga $\mathrm{H}_{5}$ diterima. Penelitian ini menemukan bahwa capital structure tidak dapat memediasi pengaruh corporate governance terhadap kinerja intellectual capital, namun capital structure tidak dapat memediasi pengaruh risiko bank terhadap kinerja intellectual capital, sehingga $\mathrm{H}_{6}$ ditolak dan $\mathrm{H}_{7}$ diterima.

Saran. Hasil penelitian menunjukan bahwa corporate governance yang diproksikan dengan nilai komposit self assessment CG tidak memiliki pengaruh signifikan terhadap intellectual capital performace. Hal ini bisa disebabkan karena dalam melakukan penilaian ini kebanyakan manajemen perusahaan kebanyakan memberikan nilai komposit 2 dengan predikat "baik". Hal ini menyebabkan ratarata nilai komposit perusahaan perbankan ada di angka 2, sehingga bagi manajemen perusahaan untuk bisa mengetahui penerapan corporate governance secara lebih detail dan representative untuk mendukung peningkatan kinerja intellectual capital bisa meneliti corporate governance dengan proksi yang berbeda dan bisa sesuai dengan kondisi yang sebenarnya. Sebagaimana diketahui bahwa intellectual capital merupakan hal yang penting dalam knowledge-based era ini.

Keterbatasan Penelitian. Keterbatasan yang terdapat dalam penelitian ini adalah: 1) Data yang digunakan dalam penelitian ini adalah data perusahaan perbankan yang terdaftar di Bursa Efek Indonesia tahun 2017 hingga 2019. Untuk penelitian selanjutnya diharapkan dapat menggunakan data perusahaan lain selain perusahaan perbankan dan menambah rentang tahun penelitian, 2) Variabel dependen yang digunakan dalam penelitian ini hanya corporate governance dan risiko bank. Untuk penelitian selanjutnya diharapkan dapat menambah variabel dependen yang digunakan agar hasilnya dapat merepresentasikan keadaan yang sebenarnya, 3) Proksi untuk variabel corporate governance menggunakan nilai komposit self assessment corporate governance. Untuk penelitian selanjutnya diharapkan dapat menggunakan proksi lain selain nilai komposit self assessment untuk variabel corporate governance.

Implikasi Penelitian. Berdasarkan hasil penelitian tersebut dapat dikemukakan implikasi secara teoritis dan praktis sebagai berikut: a) Hasil penelitian ini dapat digunakan untuk menambah literatur penelitian mengenai corporate governance, risiko bank, capital structure, serta kinerja intellectual capital, b) Hasil penelitian ini dapat digunakan para praktisi untuk memahami corporate governance, risiko bank, capital structure, serta kinerja intellectual capital.

\section{DAFTAR PUSTAKA}

Alfathurahman, Muhammad Qori. 2018. "Analisis Determinan Kinerja Intellectual Capital (Studi Empiris pada Perusahaan Sektor Industri Barang Konsumsi yang Listing di Bursa Efek Indonesia”. Jurnal Fakultas Ekonomi Universitas Negeri Yogyakarta.

Bayunitri, Bunga Indah. dan Taufik Akbar Malik. 2015. Analisis Faktor-faktor yang Mempengaruhi Struktur Modal pada Perusahaan Manufaktur yang Listing di Bursa Efek Indonesia. Study dan Accounting Research. Vol. XII. No. 1.

Ghozali, Imam. 2009. Aplikasi Analisis Multivariate dengan Program SPSS .Semarang : UNDIP.

Ghozali, Imam. 2011. Aplikasi Analisis Multivariate Dengan Program SPSS. Semarang: Badan Penerbit Universitas Diponegoro.

Ghozali, Imam. 2013. Aplikasi Analisis Multivariate Dengan Program SPSS. Semarang: Badan Penerbit Universitas Diponegoro.

Ghozali, Imam. 2018. Aplikasi Analisis 
Multivariate dengan Program IBM SPSS 25. Badan Penerbit Universitas Diponegoro: Semarang.

Hsu, I Chieh. dan Rajiv Sabherwal. 2011. "From Intellectual Capital to Firm Performance: The Mediating Role of Knowledge Management Capabilities. IEEE Transactions on Engineering Management . Vol. 58. No.3.

Kurniawan, Vito Janitra dan Shiddiq Nur Rahardjo. 2014. "Pengaruh Antara Tata Kelola Perusahaan (Corporate Governance) dengan Struktur Modal Perusahaan". Diponegoro Journal of Accounting. Vol. 3. No. 3.

Kusumo, Taufiq Andre dan Paulus Basuki Hadiprajitno. 2017. "Pengaruh Good Corporate Governance Terhadap Struktur Modal (Studi Empiris pada Perusahaan Pertambangan yang Listing di BEI Tahun 2011-2014)". Diponegoro Journal of Accounting. Vol. 6. No. 2.

Mahmudi, Bambang dan Enok Nurhyati. 2014. "The Influence of Board Governance Characteristics on Intellectual Capital Performance (Empirical Study on Listed Banks in BEI 2008 - 2012)". Society of Interdisciplinary Business Research. Vol. 4. No. 1.

Oktavian, Magu dan Nurmala Ahmar. 2019. "The Effect of Managerial Ownership, Institutional Ownership, and Foreign Ownership on Intellectual Capital". The Indonesian Accounting Review. Vol. 9. No. 1.

Pulic, A. 2000. "Measuring the performance of intellectual potential in knowledge economy". Paper presented at the 2nd McMaster Word Congress on Measuring and Managing Intellectual Capital by the Austrian Team for Intellectual Potential".

Pulic, Ante. 1998. "Measuring the Performance of Intellectual Potential in Knowledge Economy". McMaster World Congress on Measuring and Managing Intellectual Capital by the Austrian Team for Intellectual Potential.

Putri, Rahmi Aulia dan Yolandafitri Zulvia. 2019. "Pengaruh Corporate Governance Terhadap Struktur Modal Pada Perusahaan Manufaktur yang

Terdaftar di Bursa Efek Indonesia Tahun 2014-2017”. Jurnal EcoGen. Vol. 2. No. 4.
Ritha, Henny. 2016. "Faktor-faktor yang Mempengaruhi Struktur Modal Perusahaan Konstruksi di Bursa Efek Indonesia Periode 2009-2011". Majalah Ilmiah Ilmu Administrasi. Vol. XIII. No. 02.

Sangkala. 2006. Intellectual Capital Management: Strategi Baru Membangun Daya Saing Perusahaan. Jakarta: YAPENSI.

Sefidgar, Mohammad. Sara Maleki, dan Mehrzad Minouei. 2015. "Studying

Factors that Affect Intellectual Capital Performance in Listed Banks in Tehran Stock Exchange". Indian Journal of Fundamental and Applied Life Sciences. Vol. 5 (S1), pp. 769-776.Sugiarti, Yenny. 2012. "Kinerja Intellectual Capital Perbankan Indonesia: Penerapan Model Pulic dan Analisis Panel Data". Jurnal Keuangan dan Perbankan. Vol. 16. No. 2. pp. 304-317.

Supradnya, I Nyoman Trisna. I Gusti Ayu Made Asri Dwija Putrid dan I Gusti Ketut Agung Ulupui. 2016. "Pengaruh Jenis Industri, Kepemilikan Manajerial, Kepemilikan Institusional, dan Kepemilikan Asing Terhadap Kinerja Modal Intelektual”. Simposium Nasional Akuntansi XIX.

Tan et al. 2007. "Intellectual Capital and Financial Returns of Companies". Journal of Intellectual Capital. Vol. 8. No.1. pp. 7695.The Organization for Economic Cooperation and Development (OECD). 2004. The Revised OECD Principles of Corporate Governance and Their Relevance to Non-OECD Countries. Diakses 05 April 2020 dari http://www.oecd.org.

Trinita, Olivia dan Sofia Prima Dewi. 2019. "Faktor-faktor yang Mempengaruhi Kinerja Perusahaan Manufaktur yang Terdaftar di BEI". Jurnal Multiparadigma Akuntansi. Vol. 1. No. 3. pp. 748-756.

Ulum, Ihyaul. 2006. "Intellectual Capital dan Kinerja Keuangan Perusahaan: Suatu Analisis dengan Pendekatan Partial Least Squares".

Ulum, Ihyaul. 2015. Intellectual Capital: Konsep dan Kajian Empiris.

Yogyakarta: Graha Ilmu.

Ulum, Ihyaul. 2017. Intellectual Capital: Model Pengukuran, Framework Pengungkapan dan Kinerja Organisasi. Yogyakarta: Graha Ilmu. 